\title{
KURIKULUM PENDIDIKAN TINGGI EMPAT NEGARA INDONESIA, INDIA, IRAK DAN TURKI
}

\author{
Siti Aimah \\ Institut Agama Islam Darussalam Blokagung Banyuwangi, Indonesia \\ E-mail: sitiaimah1@iaida.ac.id
}

\begin{abstract}
Abstrak: Kurikulum sebagai sebuah konsep pendidikan di perguruan tinggi khususnya harus mampu mengakomodir perkembangan ilmu pengetahuan (scientific vision), kebutuhan masyarakat (societal needs) dan tentu saja kebutuhan pengguna lulusan (stakeholder needs). Tanpa meninggalkan ciri khas, masing-masing negara memiliki kurikulum terstuktur dan sistematis yang menjadi panduan dalam pelaksanaan pendidikan yang dikembangkannya untuk mencapai tujuan yang ditetapkan. Meskipun secara umum kurikulum pada setiap negara memiliki persamaan akan tetapi secara spesifik masing-masing negara memiliki keunikan yang berbeda antara satu negara dengan negara lainnya. Diantara Empat negara; Indonesia, India, Irak dan Turki, persamaannya adalah sama-sama fokus mengkaji dan mengembangkan teori-teori Islam klasik yang terdapat pada kitab-kitab salaf menggunakan sistem-sistem modern dengan mengadopsi pola pendidikan barat, meskipun dengan tetap mempertahankan ciri khas dari pola pendidikan Islam yang cenderung berorientasi pada pembinaan karakter dan budi pekerti yang mulia. Sedangkan perbedaannya yaitu pada orientasi mutu pembelajaran seperti yang terjadi di Indonesia dan India, perbedaan pada otoritas pelaksanaan kurikulum seperti yang ada di Indonesia dan Irak, dan perbedaan pada otonomi akademik seperti yang terdapat di Indonesia dan Turki.
\end{abstract}

Kata Kunci: Kurikulum, Pendidikan Tinggi, Indonesia, India, Irak, Turki

\section{Pendahuluan}

Pendidikan dalam Islam merupakan sebuah rangkaian proses pemberdayaan manusia menjuju kedewasaan, baik secara akal, mental maupun moral, untuk menjalankan fungsi kemanusiaan yang diemban sebagai seorang hamba dihadapan Khaliq-nya dan juga sebagai Khalifatu fil ardh (pemelihara) pada alam semesta ini. Dengan demikian, fungsi utama pendidikan adalah mempersiapkan generasi penerus (peserta didik) dengan kemampuan dan keahliannya (skill) yang diperlukan agar memiliki kemampuan dan kesiapan untuk terjun ketengah lingkungan masyarakat.

Dalam lintasan sejarah peradaban Islam, peran pendidikan ini benar-benar bisa diaktualisakan dan diaplikasikan tepatnya pada zaman kejayaan Islam, yang mana itu semua adalah sebuah proses dari sekian lama kaum musliminin berkecimpung dalam naungan Ilmu-ilmu keIslaman yang bersumber dari Quran dan Sunnah. Hal ini dapat kita saksikan, dimana pendidikan benar-benar mampu membentuk peradaban sehingga peradaban Islam menjadi peradaban terdepan sekaligus peradaban yang mewarnai sepanjang jazirah Arab, Afrika, Asia Barat hingga Eropa timur. Untuk itu, adanya sebuah paradigma pendidikan yang memberdayakan peserta didik merupakan sebuah keniscayaan. Kamajuan peradaban dan kebudayaan islam pada masa keemasan sepanjang abad pertengahan, dimana kebudayaan dan peradaban Islam berhasil memberikan Illuminatif (pencerahan) jazirah Arab, Afrika, Asia Barat dan Eropa Timur, hal ini merupakan bukti sejarah yang takterbantahkan bahwa peradaban Islam tidak lepas dari peran serta adanya sistem pendidikan berbasis Kurikulum Samawi.

Makna dan tujuan pendidikan adalah dua unsur yang saling berkaitan, yang telah menarik para filosof dan pendidik sejak dahulu. Adanya perbedaan konseptualisasi dan perbedaan kedua unsur ini disebabkan oleh adanya perbedaan dalam memahami hakikat, peranan, dan tujuan hidup manusia di dunia, yang ternyata sangat berkaitan dengan serentetan pertanyaan mengenai hakikat ilmu pengetahuan dan Realitas Mutlak. Oleh karena itu, tidaklah mengherankan jika kita 
menjumpai perbedaan pendapat di kalangan filosof dan pendidik, terutama yang ada di Barat, mengenai tujuan dan kurikulum pendidikan.

Secara umum, menurut Wan Daud ${ }^{1}$ ada dua pandangan teoritis mengenai tujuan pendidikan, masing-masing dengan tingkat keragamannya tersendiri. Pandangan teoretis yang pertama berorintasi kemasyarakatan, yaitu pandangan yang menganggap pendidikan sebagai sarana utama dalam menciptakan rakyat yang baik, baik untuk sistem pemerintahan demokratis, oligarkis (Sebagian kelompok masyarakat yang memegang kendali sebuah Negara) maupun monarkis. Pandangan teoretis yang kedua lebih berorientasi kepada individu, yang lebih memfokuskan diri pada kebutuhan, daya tampung dan minat pelajar.

Selanjutnya, sistem pendidikan yang diterapkan di negara-negara yang ada di dunia ini berorientasi kemasyarakatan, kenegaraan. Brubacher ${ }^{2}$ menyatakan hubungan pendidikan dengan masyarakat mencakup hubungan pendidikan dan perubahan sosial, tatanan ekonomi, politik, dan negara, karena pendidikan itu terjadi di masyarakat, dengan sumber daya masyarakat, dan untuk masyrakat, maka pendidikan dituntut untuk mampu memperhitungkan dan melakukan antisipasi terhadap perkembangan sosial, ekonomi, politik dan kenegaraan secara simultan. Secara mikro pendidikan senantiasa memperhitungkan individualitas atau karakteristik perbedaan antara individu peserta didik.

Pemikir muslim kontemporer Muslim, Al-Attas ${ }^{3}$ mendefinisikan arti pendidikan secara sistematis, menegaskan dan menjelaskan bahwa tujuan pendidikan menurut Islam bukanlah untuk menghasilkan warga negara dan pekerja yang baik. Sebaliknya, tujuan tersebut adalah untuk menciptakan manusia yang baik. Hal ini yang diuraikannya secara jelas dalam bukunya, Islam and Secularism. "Tujuan mencari ilmu adalah untuk menanamkan kebaikan ataupun keadilan dalam diri manusia sebagai seorang manusia dan individu, bukan hanya sebagai seorang warga negara ataupun anggota masyarakat. Yang perlu ditekankan (dalam pendidikan) adalah nilai manusia sebagai manusia sejati, sebagai warga kota, sebagai warga negara dalam kerajaanya yang mikro, sebagai sesuatu yang bersifat spiritual, (dengan demikian yang ditekankan itu) bukanlah nilai manusia sebagai entitas fisik yang diukur dalam konteks pragmatis dan utilitarian berdasarkan kegunaanya bagi negara, masyarakat, dan dunia.

Dalam ulasan ini akan dibahas tentang deskripsi kurikulum pendidikan tinggi di empat negara yakni: (1) Indonesia; (2) India; (3) Irak; (4) Turki. Selain itu juga akan membahas tentang paradigma persamaan dan perbedaan kurikulum pendidikan di empat negara tersebut. Oleh karena itulah tipologi penulisan ulasan ini adalah deskriptif. Karena tujuannya hanya untuk mengetahui kurikulum pendidikan di empat negara dan untuk mengetahui paradigma persamaan dan perbedaan secara umum dari kurukulum di empat negara tersebut.

\section{Deskripsi Kurikulum Empat Negara}

\section{Indonesia}

Pendidikan Islam di Indonesia tidak pernah lepas dari semangat penyebaran Islam yang dilakukan secara intensif oleh para pendahulu dalam kerangka perpaduan antara konteks keindonesiaan dengan keislaman. Tak heran, jika pada awalnya pendidikan Islam tampak sangat tradisional dalam bentuk halaqah-halaqah. Namun seiring dengan kemajuan jaman menurut Misri $^{4}$ modernisasi pendidikan Islam mulai tampak dengan diambilnya bentuk madrasah, sebagai salah satu pendidikan Islam, selain pesantren. Menurut Amirah ${ }^{5}$ modernisasi pendidikan Islam ini dilakukan untuk memenuhi target atau tujuan pendidikan

\footnotetext{
${ }^{1}$ Wan daud, Wan Mohd Nor, Filsafat dan Praktek Pendidikan Islam (Bandung: Mizan, 2003), 163

${ }^{2}$ Jhon S. Brubacher, Modern Philosophies of Education (New York: McGraw Hill, Inc, 1982), 175

3 Al-Attas, Islam and Secularism (Lahore: Suhail Academy, 2003), 163

${ }^{4}$ Muhammad Munir Misri, al-Tarbiyyah al-Islamiyyah Ushuluba wa Tathannuruba fi al-Bilad al-'Arabiyyah (Kairo: 'Alam al-kutub, 1977), 98

${ }^{5}$ Ibrahim Basyuni Amirah, Tadris al-'Ulum wa al-Tarbiyyah al-Islamiyyah (TTP: Dar al-Ma’arif, 1978), 108-111
} 
Islam yang berorientasi individual dan kemasyarakatan. Secara umum, ada dua pandangan teoretis mengenai tujuan pendidikan Islam.

Pandangan teoretis yang pertama berorientasi kemasyarakatan, yaitu pandangan yang menganggap pendidikan sebagai sarana utama dalam menciptakan masyarakat yang baik, baik untuk sistem pemerintahan demokratis, oligarkis, maupun monarkis. Pendidikan menurut Wan Daud ${ }^{6}$ bertujuan mempersiapkan manusia yang bisa berperan dan menyesuaikan diri dalam masyarakatnya masing-masing. Berdasarkan hal ini, tujuan dan terget pendidikan dengan sendirinya diambil dari dan diupayakan untuk memperkuat kepercayaan, sikap ilmu pengetahuan, dan sejumlah keahlian yang sudah diterima dan sangat berguna bagi masyarakat. Konsekuensinya, karena kepercayaan, sikap, ilmu pengetahuan, dan keahlian yang bermanfaat dan diterima oleh sebuah masyarakat itu senantiasa berubah, mereka berpendapat bahwa pendidikan dalam masyarakat tersebut harus bisa mempersiapkan peserta didiknya menghadapi segala bentuk perubahan yang ada.

Pandangan teoretis yang kedua lebih berorientasi kepada individu, yang lebih memfokuskan diri pada kebutuhan, daya tampung, dan minat belajar. Pandangan ini menurut $\mathrm{Azra}^{7}$ terdiri dari dua aliran. Aliran pertama, berpendapat bahwa tujuan utama pendidikan adalah mempersiapkan peserta didik agar bisa meraih kebahagiaan yang optimal melalui pencapaian kesuksesan kehidupan bermasyarakat dan ekonomi, jauh lebih berhasil dari yang pernah dicapai oleh orangtua mereka. Dengan demikian, pendidikan adalah jenjang mobilitas sosial ekonomi suatu masyarakat tertentu. Aliran kedua lebih menekankan peningkatan intelektual, kekayaan, dan keseimbangan jiwa peserta didik.

Dua orientasi studi Islam tersebut dikembangkan di lingkungan Perguruan Tinggi Agama Islam (PTAI), masih dijalankan sesuai dengan tingkat kebutuhannya. Namun demikian, jika dilihat dari perkembangan yang terjadi di UIN, IAIN, dan STAIN, menunjukkan kecenderungan orientasi studi ke Barat. Hal ini dapat dilihat dari semakin besarnya jumlah mahasiswa yang dikirim ke universitas-universitas Barat, semacam McGill University, Leiden University, Ohio Institute, dan lainnya. Pasca generasi Harun Nasution dan Mukti Ali menunjukkan meningkatnya gelombang pengiriman mahasiswa ke Amerika Serikat, Kanada, Australia, Belanda, Jerman, dan Perancis.

Tak heran jika dekade 80 -an dan 90 -an terjadi perubahan besar dalam paradigma Islam di kampuskampus agama (PTAI). Kecenderungan pertama, terjadinya pergeseran dari kajiankajian Islam yang lebih bersifat normatif kepada yang lebih historis, sosiologis, dan empiris. Pendekatan normatif dalam kajian Islam menghasilkan pandangan serba idealistik terhadap Islam, yang pada gilirannya membuat kaum Muslimin melupakan atau meniscayakan realitas, dan karena itu, sering mengakibatkan mereka terjebak dalam "kepuasan batin" yang semu. Sebaliknya pendekatan historis dan sosiologis membuka mata mahasiswa di lingkungan PTAI tentang realitas yang dihadapi Islam dan kaum Muslimin dalam perkembangan dan perubahan masyarakat.

Kecenderungan kedua, orientasi keilmuwan yang lebih luas. Jika pada masa sebelumnya orientasi keilmuwan cenderung ke Timur Tengah, khususnya Universitas al-Azhar, dalam dua dasawarsa terakhir kelihatan semakin luas dan beragam. Dalam konteks ini menurut pandangan Azra ${ }^{8}$ model pendekatan Barat terhadap Islam mulai banyak bermunculan; yang pada pokoknya cenderung lebih bersifat historis dan sosiologis. Pendekatan seperti ini mulai menemukan momentumnya dengan kembalinya sejumlah tamatan universitas Barat untuk mengajar di UIN, IAIN, STAIN, dan lainnya. Mereka kembali secara bergelombang, dimulai dengan generasi Mukti Ali dan Harun Nasution, dan kemudian disusul

\footnotetext{
${ }^{6}$ Wan daud, Wan Mohd Nor, Filsafat dan Praktek Pendidikan Islam (Bandung: Mizan, 2003), 163

${ }^{7}$ Azyumardi Azra, Pendidikan Islam, Tradisi dan Modernisasi menuju Milenium Baru (Jakarta: Logos, 2000), 18

${ }^{8}$ Azra, Pendidikan Islam, 229-230
} 
kelompok tamatan McGill University. Gelombang selanjutnya adalah mereka yang dikirim belajar ke beberapa universitas Amerika pada masa Menteri Agama, Munawir Sjadzali.

Kendatipun orientasi studi Islam di Indonesia lebih cenderung ke Barat, studi di Timur Tengah tetap memiliki nilai penting, terutama dalam memahami aspek doktrinal, yang menjadi basis ilmu pengetahuan dalam Islam. Dengan demikian, orientasi studi islam di Timur dan Barat tetap signifikan dalam rangka pengembangan pendidikan Islam di lingkungan PTAI seluruh Indonesia.

UIN dan IAIN yang kurikulumnya merupakan rujukan bagi sekolah tinggi dan institut yang tersebar di seluruh Indonesia masih belum mampu menghadirkan kurikulum yang berisi elemen-elemen yang membentuk pandangan hidup Islam, yang di dalamnya metafisika dan epistemologi Islam dikonseptualisasikan dan dituangkan dalam matakuliah wajib bagi semua fakultas sehingga menjadi asas bagi semua disiplin ilmu. Pembagian fakultas Ushuluddin, Syariah, Tarbiyah, Adab, dan Dakwah masih memerlukan pengembangan lebih lanjut sehingga mencerminkan makna al-jami'ah atau kulliyah yang berarti universal. Kurikulumnya dalam pandangan Fahmi ${ }^{9}$ perlu diorientasikan agar dapat menghasilkan sarjana-sarjana yang tidak hanya memiliki otoritas di bidangnya, tetapi juga otoritas dalam ilmu-ilmu keislaman di tingkat nasional dan internasional. Fahmi juga berpendapat bahwa jika di UIN, IAIN dan perguruan tinggi Islam lainnya ditanamkan konsep pandangan hidup Islam dengan pandangan metafisika yang sistematis, para mahasiswa akan dengan mudah mengidentifikasi isu-isu itu sebagai konsep metafisika dan epistemologi yang bukan berasal dari pandangan hidup dan tradisi pemikiran Islam.

Karena itulah, kini, mulai diupayakan pengembangan pendidikan Islam yang mengarah pada tuntutan perbaikan mutu penyelenggaran, manajemen, kurikulum dengan standar internasional. Salah satunya adalah dengan membuka kelas internasional (pendidikan Islam), yang diharapkan dapat bersaing di tingkat global. Inilah yang sedang diupayakan oleh Departemen Agama dengan membuka Fakultas/Jurusan baru yang memiliki kualifikasi internasional. Di Universitas Islam Negeri (UIN) Syariaf Hidayatullah Jakarta, telah dibuka Fakultas Dirasat Islamiyah (setara dengan S-1) yang berorientasi pada studi Islam di Timur Tengah, dan Kelas Interdisipliner (setara dengan S-2) yang berorientasi pada studi Islam di Barat. Di tempat lain, yakni UIN Sunan Kalijaga dan UIN Malang juga membuka Fakultas/Jurusan baru yang memiliki kualifikasi internasional.

\section{India}

Salah satu perguruan tinggi Islam di India adalah Jamia Millia Islamia. Jamia Millia Islamia juga merupakan salah satu kampus terbaik yang terdapat di New Delhi, India. Jamia Millia Islamia yang merupakan kampus bermayoritas Muslim dikenal dengan kualitasnya dalam sistem pembelajaran dan penelitian serta telah menghasilkan sarjana di berbagai bidang keilmuan, khususnya yang berkaitan dengan ilmu-ilmu keislaman. Walaupun mayoritas sivitas akademika di kampus ini beragama Islam, namun kampus ini tidak membedakan kasta, agama maupun ras. Jamia Millia Islamia didirikan pada tahun 1920 di New Delhi sebagai pusat pengembangan ilmu pengetahuan oleh pemerintah .

Jamia Millia Islamia mengadopsi sistem pendidikan yang sama dengan University of Delhi, yaitu sistem Eropa dan sistem Amerika. Dengan gabungan sistem ini tingkat keseriusan belajar mahasiswa sangat tinggi. Strategi yang digunakan dalam proses pembelajaran bagi mahasiswa di Jamia Millia Islamia adalah "independent learning". Mereka lebih banyak meluangkan waktu dengan belajar sendiri dan memperbanyak waktu membaca.

Sistem evaluasi di Jamia Millia Islamia merupakan keseluruhan nilai mata kuliah mutlak diperoleh dari hasil ujian final mahasiswa, tanpa ada komponen kehadiran maupun tugas-

\footnotetext{
${ }^{9}$ Hamid Fahmi, dkk. "Pengantar Penerjemab" dalam Wan Mohd Nor Wan Daud, Filsafat dan Praktik. 2003, 102
} 
tugas. Jadi tidak ada kewajiban bagi mahasiswa untuk hadir penuh dalam perkuliahan, hanya saja mahasiswa akan kesulitan untuk mengikuti ujian jika tidak mengikuti perkuliahan dengan dosen di kelas.

Di kampus ini, metode yang dipakai adalah metode chapter. Artinya, setiap tahun ajaran mahasiswa diberikan sejumlah chapter (mata kuliah) yang akan ditempuh selama satu tahun ajaran. Kualitas lulusan Jamia Milia Islamia University setara dengan lulusan kampus-kampus Eropa dan Amerika, terbukti dengan masuknya Jamia Milia Islamia University ke dalam 100 universitas terkemuka se-India. Hal ini disebabkan tingginya kualitas dan penekanan keilmuan dalam proses belajar mengajar terutama penguasaan bahasa asing. Pada dasarnya, fasilitas belajar mengajar yang disediakan di kedua kampus ini lengkap adanya namun dalam kondisi sederhana. Di kedua kampus ini terdapat, hostel atau asrama bagi mahasiswa, sarana olah raga, auditorium, panggung kesenian, laboratorium dan kantin.

Bicara tentang gaji bagi pengajar, tidak tampak sesejahtera gaya hidup profesorprofesor. Kehidupan mereka jauh dari kesan mewah. Tidak seperti kebanyakan yang berlaku di Indonesia, keunggulan dan prestise seorang akademisi tidak diukur dengan indikator material, namun mengarah pada kultur akademis yang mencipta, dengan seberapa sering keilmuan dan pemikirannya yang dicurahkan dalam bentuk karya tulis masuk dalam jurnal internasional dan seberapa tinggi frekuensi mengajar di universitas lain terutama kampus-kampus di luar negeri dan masih banyak lagi hal yang menjadi indikator bagi seorang profesor yang berkualitas yang masih bernuansa akademik, mutu jauh lebih penting bagi India.

Adapun manajemen pendidikan secara otorita yakni sistem pendidikannya dipengaruhi oleh Mahatma Ghandi yang memiliki gagasan untuk membentuk "kepribadian yang utuh, kreatif dan produktif'. Sementara itu pendanaan pendidikannya, sejak tahun 1976, pemerintahan pusat telah menetapkan bertanggung jawab atas pembiayaan dan pengaturan standar pendidikan atas sampai menengah dan mengadakan koordinasi dengan program pendidikan tinggi.

Sedangkan kurikulum dan metodologi pengajaran serta struktur dan kurikulum pendidikan di India secara esensial dipengaruhi oleh sistem pendidikan Inggris karena latar belakang penjajahannya. Namun setelah merdeka, upaya pendidikan ditekankan pada ekspansi yang cepat dibandingkan dengan reformasi menyeluruh. Maka konstitusi yang berlaku pada tahun 1950 selanjutnya menegaskan prinsip bahwa pendidikan merupakan penyampaian materi dan oleh karenanya berada dibawah kebijakan pemerintah sedangkan tugas menteri pendidikannya adalah membantu pemerintah melalui penyediaan bimbingan dan dana. Pasal dalam konstitusi India menyatakan perlindungan hak bagi lembaga swasta untuk menyelenggarakan pendidikan dan menerima bantuan dari pemerintah serta menyediakan standar tertentu yang harus dipenuhi oleh lembaga tersebut. Jadi masalah pendidikan pada dasarnya adalah tanggung jawab pemerintah. Perencanaan dan koordinasi pendidikan diimplementasikan melalui kebijakan umum yang telah diletakkan oleh badan penasehat urusan pendidikan.

Kurikulum bidang spesialisasi di jenjang pendidikan tinggi terkait dengan disiplin ilmu tradisional seperti sejarah, sastra inggris dan ilmu politik. Ketika seorang mahasiswa telah memilih jurusan tertentu, ia tidak dapat merubah spesialisasinya. Beberapa universitas telah memulai memberikan program studi umum atas dasar eksperimen. Mahasiswa yang cerdas cenderung masuk ke jurusan fisika, kimia, teknik atau kedokteran. Metode pendidikan masih menekankan pada peranan hafalan tetapi ada beberapa jurusan di universitas yang mendorong dilakukannya metode penelitian (inquiri). Komisi beasiswa universitas telah mendirikan berbagai pusat studi lanjutan di berbagai universitas. Dari subsidi pusat-pusat inilah kemajuan riset dan pelatihan dikembangkan.

Dalam prosesnya, pendidikan di India berlangsung di rumah (keluarga) dan sekolah. Materi pelajaran yang diajarkan yaitu astronomi, matematik, pengetahuan tentang obat-obatan, hukum, kesusasteraan, sejarah. Soal mutu pendidikan di India sekarang sudah dikatakan tinggi 
(berkualitas). Beberapa institut di sana sudah menerapkan kurikulum dan metode proses belajar mengajar seperti halnya model Harvard. Salah satu perguruan tinggi Islam di India adalah Jamia Millia Islamia. Jamia Millia Islamia juga merupakan salah satu kampus terbaik yang terdapat di New Delhi, India. Jamia Millia Islamia yang merupakan kampus bermayoritas Muslim dikenal dengan kualitasnya dalam sistem pembelajaran dan penelitian serta telah menghasilkan sarjana di berbagai bidang keilmuan, khususnya yang berkaitan dengan ilmuilmu keislaman. Jamia Millia Islamia mengadopsi sistem pendidikan yang sama dengan University of Delhi, yaitu sistem Eropa dan sistem Amerika.

Dengan gabungan sistem ini tingkat keseriusan belajar mahasiswa sangat tinggi. Strategi yang digunakan dalam proses pembelajaran bagi mahasiswa di Jamia Millia Islamia adalah "independentlearning". Pada dasarnya, fasilitas belajar mengajar yang disediakan di kedua kampus ini lengkap adanya namun dalam kondisi sederhana. Soal gaji bagi pengajar, kehidupan mereka jauh dari kesan mewah. Tidak seperti kebanyakan yang berlaku di Indonesia, keunggulan dan prestise seorang akademisi tidak diukur dengan indikator material, namun mengarah pada kultur akademis yang mencipta, dengan seberapa sering keilmuan dan pemikirannya yang dicurahkan dalam bentuk karya tulis masuk dalam jurnal internasional dan seberapa tinggi frekuensi mengajar di universitas lain terutama di kampus-kampus di luar negeri dan masih banyak lagi hal yang menjadi indikator bagi seorang profesor yang berkualitas yang masih bernuansa akademik.

Pendidikan di India dikendalikan oleh pemerintah pusat dan pemerintah daerah yang keduanya bertanggung jawab atas pendidikan dengan kekhususan dimana daerah mempunyai otonomi untuk mengatur hal khusus dalam pendidikan. Peningkatan sistem pendidikan tersebut sedikit banyak dapat memberikan andil dalam peningkatan ekonomi, meskipun belum sesuai yang diharapkan.

\section{Irak}

Madrasah pada abad pertengahan, terutama di masa kejayaan Islam (khususnya di Irak), merupakan lembaga pendidikan yang setingkat dengan perguruan tinggi pada masa sekarang. Hal ini disampaikan Makdisi ${ }^{10}$ bahwa perguruan tinggi atau college pada masa Islam klasik diawali di kompleks masjid kemudian di madrasah.

Lembaga pendidikan madrasah pada awalnya berdiri karena peran dari pemerintah yang peduli untuk mendidik masyarakat agar memiliki pengetahuan. Pada masa kejayaan Dinasti Abbasiyah, segenap kemampuan dan perhatian dicurahkan untuk membangun peradaban yang berpusat di kota Bagdad dengan mendirikan istana dan bangunan untuk pengembangan ilmu pengetahuan dan intelektual, antara lain perpustakaan seperti Baitul Hikmah dan beberapa madrasah seperti Nizamiyah dan Mustanshiriyah.

Dikarenakan lembaga pendidikan madrasah didirikan oleh penguasa, keberadaannya terpengaruh juga oleh kuat lemahnya kekuasaan dinasti atau pemerintah. Nizar ${ }^{11}$, mengutip pendapat Ibnu Khaldun, bahwa pasang surut sebuah dinasti merupakan bagian dari siklus sejarah yang bersifat faktual. Sebagai sebuah pemerintahan atau kekuasaan Islam yang pernah meraih kejayaan, juga tidak lepas dari kemunduran atau keruntuhan, begitu juga pengaruhnya dengan pendidikan.

Madrasah Mustanshiriyah dibangun pada periode Dinasti Abbasiyah kedua pada masa Dinasti Saljuq. Kelahiran madrasah ini berada pada kejayaan Dinasti Abbasiyah yang hampir runtuh. Suasana Baghdad saat itu menghadapi konflik aliran dalam Islam yang sering menimbulkan konflik berdarah. Di samping itu, muncul juga dinasti-dinasti kecil yang ingin memerdekakan diri dari kekuasaan Dinasti Abbasiyah yang berpusat di Baghdad.

\footnotetext{
${ }^{10}$ George Makdisi, The Rise of Colleges, Institutions of Learning in Islam and the West. (Edinburgh : Edinburgh University Press, 1981), 23

${ }^{11}$ Samsul Nizar, Sejarah Pendidikan Islam (Jakarta : Kencana Predana Media Group, 2009), 171
} 
Bosworth $^{12}$ menulis bahwa sebelum madrasah Mustanshiriyah berdiri, pada tahun 1108 M, Ayyarun yang cukup aktif di masa Dinasti Saljuq, mereka menjarah toko-toko dan rumah-rumah. Perbedaan paham sektarian menimbulkan perkelahian dan kehancuran. Orang-orang berpaham Hambali melawan orang-orang Syafi'i dan orangorang Sunni melawan orang-orang Syi'ah.

Peristiwa ini sangat memprihatinkan dan pada periode khalifah al-Mustanshir Billah, diupayakan olehnya untuk menjaga persatuan dan kesatuan umat Islam dengan mendirikan madrasah yang kurikulumnya menyajikan pandangan empat madzhab hukum Islam. Madrasah Mustanshiriyah menurut Nashabe ${ }^{13}$ sebagai lembaga pendidikan Islam pembangunannya berlangsung enam tahun, dimulai tahun $623 \mathrm{H} / 1228 \mathrm{M}$ selesai tahun $631 \mathrm{H} / 1233$ M. Peresmiannya dilangsungkan tanggal 5 Rajab $631 \mathrm{H} / 1233$ M. Pada saat upacara inagurasi, sudah ada daftar para anggota administrasinya, para profesor, repetitor, karyawan resmi di madrasah dan pembagian ruang ('iwan) untuk profesorprofesor yang berbeda. Semua kegiatan ini dilaksanakan oleh Naib al-Wazarah yang merupakan wakil resmi pemerintah pada saat upacara. Juga hadir para gubernur (wulat, jamak dari wali), bagian pengadilan (hajib), hakim-hakim, guru-guru, syaikh sufi (masayikh rubat), para khatib, sastrawan, para qari' dan para tamu asing.

Madrasah Mustanshiriyah mampu melanjutkan kegiatannya dengan makmur dari waqaf, termasuk juga madrasah-madrasah yang lain memiliki sistem yang bertujuan untuk mencetak lulusan yang mengabdi pada birokrasi negara. Masih menurut Nasabhe tidak banyak diperoleh keterangan tertulis dalam sejarah tentang kemajanu atau kemunduran madrasah Mustanshiriyah saat ini. Ketika Irak di bawah kekuasaan Qara Quyunlu tahun 1411-1469 M. dan Aq-Quyunlu pada 1469-1500 M., banyak terjadi perang kecil dan kerusuhan. Pemerintahan dipegang orang rakus dan tidak religius. Madrasah-madrasah yang ada di beberapa tempat terbengkalai. Namun pada saat Sulayman Pasha menjadi wali kota Baghdad tahun 1779-1802 M, waqaf dialokasikan untuk membangun sekolah yang dikenal dengan madrasah al-Sulaymaniyah, madrasah Mustanshiriyah diubah sebagai khan atau rumah tamu.

Setelah Perang Dunia Pertama, tepatnya tahun 1921 M, Amir Faishal I mengunjungi madrasah Mustanshiriyah. Saat kunjungan itu, terdapat dua penyair besar Irak, yaitu Ma'ruf al-Rusafi dan Jamil Sidqi al-Zahawi, menyuguhkan puisi yang isinya mengingatkan orang-orang Arab tentang tradisi besar lembaga pendidikan ini untuk segera dipulihkan. Departemen Waqaf juga menuntut agar Departemen Keuangan segera merestorasi madrasah Mustanshiriyah, namun tuntutan ini ditolak. Maka melalui Pengadilan Syar'i, memutuskan bahwa Departemen Keuangan yang harus merestorasi madrasah Mustanshiriyah.Pada tahun 1945 M, Departemen Purbakala Irak melaksanakan keinginan Departemen Waqaf. Namun area madrasah Mustansairiyah yang dipakai hanya setengahnya. Di sekeliling dibuat tempat yang disebut Suq al-Rihmah, Suq alMawlakhanah, Qahwat al-Mumayyiz, al-Idarah al-Nahriyah dan Jami' al-Asafiyah.

Pada tahun 1963, para ilmuwan dan intelektual Baghdad membidani kelahiran kembali perguruan tinggi ini yang mengambil nama dari sekolah tinggi di masa kejayaannya, yaitu Universitas Al-Mustanshiriyah. Kini Mustanshiriyah merupakan lembaga perguruan tinggi modern memiliki sepuluh fakultas, dua institut dan empat pusat studi dan kajian. Fakultas-fakultas itu adalah Fakultas Hukum, Fakultas Ekonomi dan Manajemen, Fakultas Seni, Fakultas Pendidikan, Fakultas Sains, Fakultas Pendidikan Kedokteran, Fakultas Teknik, Fakultas Ilmu Politik, Fakultas Pendidikan Dasar dan Fakultas Ilmu Kedokteran Gigi.

Sebagai universitas yang berkaliber internasional, bisa terlihat antara lain dari adanya kerjasama Universitas Mustanshiriyah dengan perguruan tinggi di dunia, seperti

\footnotetext{
${ }^{12}$ C. Edmund Bosworth, Historic Cities of The Islamic World (Leiden-Boston : Brill, 2007), 120

${ }^{13}$ Hisham Nashabe, Muslim Educational Institutions (Beirut : Librairie Du Liban, 1989), 72
} 
Universitas Libanon, Universitas Ural di Rusia, Universitas Sudan, universitas-universitas di Amerika, Jerman dan Australia.

Kurikulum pendidikan di madrasah Mustanshiriyah merupakan kurikulum bercirikan kajian keislaman pada abad pertengahan, yaitu memiliki dua kategori: (1) ilmu pengetahuan dasar atau traditional sciences dan pengetahuan bahasa Arab (2) ilmu pengetahuan yang bersifat pemikiran atau rasional.

Setiap pendidik selalu mengintegrasikan dua ciri khas tersebut ke dalam materi yang diajarkan. Pemikiran yang disampaikan ini banyak mencontoh pada Imam al-Ghazali. Menurut Qadir ${ }^{14}$ pemikiran Imam al-Ghazali mengenai dua hal, yaitu perlunya pengamatan dan analisis serta perlunya keraguan.

Dengan kata lain adalah menggunakan pemikiran yang bersifat induktif, mendasarkan pengamatan kepada fakta dan fenomena, kemudian menjadi bangunan pengetahuan teoritis yang terinspirasi dari al-Qur'an. Terdapat empat bidang studi penting yang diajarkan pada masa awal pendirian madrasah Mustanshiriyah, yaitu ilmu al-Qur'an, biografi nabi Muhammad (hadits), ilmu kedokteran dan matematika. Selain itu, empat madzhab Sunni diajarkan di sana, yakni Hambali, Maliki, Syafi'i dan Hanafi. Setiap madzhab menempati pojok madrasah. Pelajaran hukum Islam (fiqih) diakui oleh Makdisi ${ }^{15}$ sebagai pelajaran unggulan di madrasah pada masa Islam klasik. Makdisi menyebut studi hukum Islam sebagai queen of the Islamic sciences.

Pembelajaran di madrasah Mustanshiriyah pada mulanya menempati masjid. Para ulama' muda mengelilingi profesor mereka dan berdiskusi. Hal ini terjadi karena mengajar merupakan tugas suci dan sering para pengajar shalat lebih dahulu sebelum mengajar. Setelah itu dalam pembelajaran di madrasah, tahap awalnya berupa hapalan, kemudian mereka mencatat segala hal yang harus ditulis. Jadi mereka secara bersamaan memperoleh dua kemampuan, yaitu menghapal dan menulis. Kemampuan ini oleh Nashabe ${ }^{16}$ diberi istilah dictating and learning through dictation atau dalam bahasa Arab dikenal dengan istilah al-imla' wa al-istimla'.

Metode diskusi dan tanya jawab sering digunakan oleh mereka. Untuk bertanya kadang-kadang dengan bentuk tertulis. Diskusi-diskusi akademik dilaksanakan dengan pertemuan atau dengan cara korespondensi yang sering diberi komentar para ulama. Juga dilaksanakan perjalanan untuk menambah ilmu (rihlah 'ilmiyyah) yang berhubungan dengan mencari literatur hadits dan sintaksis ekspresi bahasa Arab yang asing. Kegiatan pendidikan dilaksanakan dengan proses yang bagus dan metode ini banyak dilaksanakan oleh lembaga-lembaga pendidikan di masa sekarang, misalnya adalah dengan membuat makalah dan studi wisata.

\section{Turki}

Pada awalnya Turki merupakan salah satu negara yang berbentuk kerajaan. Saat ini pemerintahan turki berbentuk republik yang beribu kota di Istanbul. Republik Turki termasuk sebagai negara dan memproklamirkan diri sebagai negara sekuler, namun tidak bisa dipungkiri bahwa jiwa Islamnya tetap melekat dan tak terpisahkan dari bangsa Turki. Begitu pun berdampak terhadap kemajuan pendidikan di negara tersebut.

Masuknya sistem pendidikan modern dalam kalangan kerajaan Turki Usmani bermula sejak sultan Mahmud II (1785-1839 M ), Turki mengadakan pembaharuan dalam berbagai bidang pendidikan. Di zaman itu, madrasah serupakan satu-satunya lembaga pendidikan yang ada di kerajaan Turki Usmani. Di madrasah itu Mahmud menyadari bahwa madrasah-

\footnotetext{
${ }^{14}$ Qadir, C.A., Philosophy and Science in the Islamic World. terj. Hasan Basari. (Jakarta : Pustaka Obor Indonesia, 2002), 156

${ }^{15}$ George Makdisi, The Rise of Colleges, Institutions of Learning in Islam and the West. (Edinburgh : Edinburgh University Press, 1981), 9

${ }^{16}$ Hisham Nashabe, Muslim Educational Institutions (Beirut : Librairie Du Liban, 1989), 34
} 
madrasah tradisional tersebut tidak sesuai lagi dengan tuntunan perkembangan zaman. Oleh karena itu Turki berusaha untuk memperbaiki sistem pendidikan madrasah yang ada, agar anak-anak bisa mendapatkan pelajaran pengetahuan umum. Namun mengadakan perubahan dalam kurikulum madrasah dengan memasukkan pengetahuan-pengetahuan umum pada waktu itu sangat sulit. Karena itu, Turki mendirikan dua sekolah pengetahuan umum yang berdiri sendiri. Terpisah dari sistem madrasah tradisional yang ada. Kedua sekolah tersebut adalah: Sekolah Pengetahuan Umum (Mekteb-Ima'rif) dan Sekolah sastra (Mekteb-I Ulum Edebiye).

Setelah perubahan dari Usmani ke Republik Turki banyak reformasi di bidang pendidikan telah dibuat. Seperti di Ottomans bahasa Usmani adalah sulit, abjad Arab adalah salah satu yang sangat sulit untuk belajar, dengan rasio keaksaraan sangat rendah dan pendidikan agama adalah subjek utama banyak perubahan radikal telah dibuat. Beberapa yang penting adalah sekularisasi dan perubahan abjad.

Di Turki, pendidikan tinggi meliputi semua institusi pendidikan setelah pendidikan menengah, yang menyediakan setidaknya dua tahun pendidikan tinggi dan mendidik siswa untuk melanjutkan ke jenjang, sarjana, master atau gelar tingkat doktor. Lembaga pendidikan tinggi terdiri dari universitas, fakultas, institut, sekolah pendidikan tinggi, konservatori, sekolah kejuruan pendidikan tinggi dan pusat penelitian aplikasi. Di Turki, eskalasi pendidikan yang lebih tinggi adalah untuk mencapai tingkat kemampuan dalam menghadapi era globalisasi dunia, baik dari segi kualitas dan kuantitas, telah diadopsi sebagai tujuan utama. Rencana dan program yang dibuat selalu mencerminkan persepsi dari rencana itu sendiri.

Tujuan pendidikan tinggi adalah untuk melatih tenaga kerja dalam suatu system, prinsip-prinsip pendidikan dan pelatihan kontemporer untuk memenuhi kebutuhan Negara. Namun demikian dipendidikan tingggi juga disediakan beberapa pendidikan khusus di berbagai bidang bagi siswa yang telah menyelesaikan pendidikan menengah.

Universitas yang terdiri dari beberapa unit yang dibentuk oleh negara dan oleh hukum sebagai perusahaan publik memiliki otonomi dalam pengajaran dan penelitian. Selain itu, lembaga-lembaga pendidikan tinggi, di bawah pengawasan dan kontrol negara, juga dapat dibentuk oleh yayasan swasta sesuai dengan prosedur dan prinsip-prinsip yang ditetapkan dalam undang-undang dengan ketentuan bahwa mereka adalah non-profit di dunia. Universitas adalah lembaga pendidikan tinggi pokok. Ia memiliki otonomi akademik dan kepribadian hukum publik. Hal ini bertanggung jawab untuk melaksanakan kegiatan pendidikan tingkat tinggi, penelitian ilmiah dan publikasi. Setiap universitas terdiri dari fakultas dan sekolah empat tahun, menawarkan program yang tingkat sarjana, yang kedua dengan penekanan kejuruan, dan tahun-dua sekolah kejuruan yang menawarkan rekan) tingkat's (program pra-sarjana dari alam kejuruan ketat. Tingkat pascasarjana program terdiri dari master dan doktor program, dikoordinasi oleh lembaga untuk studi pascasarjana.

program magister ditetapkan sebagai program "dengan tesis" atau "tanpa tesis". program "Dengan tesis" gelar master yang menyelesaikan pendidikan tertentu diikuti dengan pengajuan tesis. Sementara itu program "tanpa tesis" juga bagian penyelesaian dari program sarjana namun disini disebut istilah proyek. Durasi program ini adalah dua tahun setidaknya. Akses ke program doktor membutuhkan gelar master.

Program Doktor memiliki jangka waktu minimal empat tahun yang terdiri penyelesaian kursus, lulus ujian kualifikasi doktor, serta menyiapkan dan mempertahankan tesis doktor. Medis program pelatihan khusus untuk program setara tingkat doktor, namun dilakukan dalam fakultas kedokteran dan pelatihan di rumah sakit yang dimiliki Departemen Kesehatan dan Organisasi Negara Asuransi Sosial. 


\section{Paradigma Persamaan dan Perbedaan Kurikulum Empat Negara}

\begin{tabular}{|c|c|c|c|}
\hline $\mathrm{No}$ & Nama Negara & Persamaan & Perbedaan \\
\hline 1 & Indonesia dan India & $\begin{array}{l}\text { Perguruan Tinggi } \\
\text { Islamnya sama-sama } \\
\text { mengadopsi kurikulum } \\
\text { barat, Misalnya Jamiah } \\
\text { Millia Islamia di India } \\
\text { yang cenderung } \\
\text { mencontoh kurikulum } \\
\text { Harvard University, } \\
\text { meskipun di Indonesia } \\
\text { sendiri tidak menyebut } \\
\text { nama universitas yang } \\
\text { dijadikan percontohan } \\
\text { kurikulum, tetapi sistem } \\
\text { madrasah/sekolah yang } \\
\text { dibangun pada } \\
\text { pendidikan modern, } \\
\text { termasuk perguruan } \\
\text { tinggi Islam adalah } \\
\text { warisan pola pendidikan } \\
\text { Belanda. Selain itu, } \\
\text { materi yang dikaji adalah } \\
\text { sama-sama berbasis } \\
\text { keislaman yang } \\
\text { berorientasi budi pekerti } \\
\text { mulia }\end{array}$ & $\begin{array}{l}\text { Dalam implementasi } \\
\text { kurikulum, di India } \\
\text { mutu sudah menjadi } \\
\text { prioritas utama, } \\
\text { sedangkan di } \\
\text { Indonesiakurikulum } \\
\text { masih banyak } \\
\text { diperdebatkan pada } \\
\text { prosesnya }\end{array}$ \\
\hline 2 & Indonesia dan Irak & $\begin{array}{l}\text { Kurikulumnya sama- } \\
\text { sama berorientasi pada } \\
\text { telaah kajian teori-teori } \\
\text { klasik yang terdapat pada } \\
\text { kitab-kitab salaf dengan } \\
\text { metode lebih modern } \\
\text { yang tujuannnya untuk } \\
\text { mencapai pemahaman } \\
\text { yang lebih baik pada } \\
\text { ilmu-ilmu keislaman } \\
\text { sebagai pedoman hidup } \\
\text { dan pelestarian nilai-nilai } \\
\text { Islam }\end{array}$ & $\begin{array}{l}\text { Di Indonesia, } \\
\text { Kurikulum Perguruan } \\
\text { Tinggi Islam menjadi } \\
\text { kewenangan dan } \\
\text { tanggungjawab } \\
\text { pemerintah pusat. } \\
\text { Sedangkan di Irak, } \\
\text { kurikulum perguruan } \\
\text { tinggi (Islam) menjadi } \\
\text { otorita pemerintah } \\
\text { pusat dan daerah }\end{array}$ \\
\hline 3 & Indonesia dan Turki & $\begin{array}{l}\text { Sama-sama menggunakan } \\
\text { sistem modern dalam } \\
\text { implementasi kurikulum } \\
\text { di perguruan tinggi, } \\
\text { termasuk perguruan } \\
\text { tinggi Islam. Selain itu, } \\
\text { kajian keislaman adalah } \\
\text { materi wajib bagi } \\
\text { mahasiswa }\end{array}$ & $\begin{array}{l}\text { Di Turki, Universitas } \\
\text { adalah lembaga } \\
\text { pendidikan tinggi } \\
\text { pokok yang memiliki } \\
\text { otonomi akademik dan } \\
\text { kepribadian hukum } \\
\text { publik. Sedangkan di } \\
\text { Indonesia sebaliknya }\end{array}$ \\
\hline
\end{tabular}

Sumber: Data diolah 


\section{Kesimpulan}

Kurikulum dipandang sebagai the heart/core of education, sedangkan pendidik merupakan the prominent role of education, sehingga betapapun baiknya kurikulum disusun dan dikembangkan, ujung-ujungnya banyak tergantung pada siapa pelaku atau pendidik yang mengimplementasikannya. Dalam hal ini dari empat negara yang dibahas yakni Indonesia, India, Irak dan Turki. Keempat negara tersebut memiliki cara atau metode yang kemudian menjadi ciri khas tersendiri bagi negara tersebut dalam implementasi kurikulum, khususnya kurikulum di tingkat perguruan tinggi Islamnya.

Secara umum keempat negara tersebut memiliki kesamaan dalam implementasi kurikulum pendidikan tinggi Islam, yakni sama-sama fokus mengkaji dan mengembangkan teori-teori Islam klasik yang terdapat pada kitab-kitab salaf menggunakan sistem-sistem modern dengan mengadopsi pola pendidikan barat, meskipun dengan tetap mempertahankan ciri khas dari pola pendidikan Islam yang cenderung berorientasi pada pembinaan karakter dan budi pekerti yang mulia. Meskipun demikian, dengan latar belakang yang berbeda-beda dari sejarah pendirian perguruan tinggi Islam di masing-masing negara tersebut dan sistem pemerintah keempat negara itu pada akhirnya memberikan warna berupa perbedaan dalam implementasi kurikulum pendidikan tinggi Islam, khususnya. Diantaranya adalah perbedaan pada orientasi mutu pembelajaran seperti yang terjadi di Indonesia dan India, perbedaan pada otoritas pelaksanaan kurikulum seperti yang ada di Indonesia dan Irak, dan perbedaan pada otonomi akademik seperti yang terdapat di Indonesia dan Turki.

\section{Referensi}

Al-Attas. 2003. Islam and Secularism. Lahore: Suhail Academy

Amirah, Ibrahim Basyuni. 1978. Tadris al-'Ulum wa al-Tarbiyyah al-Islamiyyah. TTP: Dar al-Ma'arif.

Azra, Azyumardi. 2000. Pendidikan Islam, Tradisi dan Modernisasi menuju Milenium Baru. Jakarta: Logos.

Brubacher, Jhon S. 1982. Modern Philosophies of Education. New York: McGraw Hill, Inc

C. Edmund, Bosworth. 2007. Historic Cities of The Islamic World. Leiden-Boston : Brill

Fahmi, Hamid, dkk. 2003. "Pengantar Penerjemah" dalam Wan Mohd Nor Wan Daud, Filsafat dan Praktik

Makdisi, George. 1981. The Rise of Colleges, Institutions of Learning in Islam and the West. Edinburgh : Edinburgh University Press

Misri, Muhammad Munir. 1977. al-Tarbiyyah al-Islamiyyah Ushuluba wa Tathanwuruha fi al-Bilad al'Arabiyyah. Kairo: 'Alam al-kutub.

Nashabe, Hisham. 1989. Muslim Educational Institutions. Beirut : Librairie Du Liban

Nizar, Samsul. 2009. Sejarah Pendidikan Islam. Jakarta : Kencana Predana Media Group

Qadir, C.A. 2002. Philosophy and Science in the Islamic World. terj. Hasan Basari. Jakarta : Pustaka Obor Indonesia

Wan daud, Wan Mohd Nor. 2003. Filsafat dan Praktek Pendidikan Islam. Bandung: Mizan. 